\title{
Development of the Composition and Method of Producing A Liquid Complex Fertilizers With A Stabilizing Additive
}

\section{U.B.NAZARBEK ${ }^{1 *}$, A.A. KADIRBAYEVA ${ }^{1}$, M.ZH.AITUREEV ${ }^{2}$, O.P.BAYISBAI ${ }^{1}$ and L.AIKOZOVA ${ }^{3}$}

\author{
'Department of Chemical Technology of Inorganic Substances, M. Auezov South \\ Kazakhstan State University, Shymkent, Kazakhstan. \\ ${ }^{2}$ Department of Chemical technology of silicate and refractory non-metallic substances. \\ M. Auezov South Kazakhstan State University, Shymkent, Kazakhstan. \\ ${ }^{3}$ Department of Chemistry. M. Auezov South Kazakhstan State University, \\ Shymkent, Kazakhstan. \\ ${ }^{*}$ Corresponding author E-mail: eplusr@bk.ru \\ http://dx.doi.org/10.13005/ojc/330335
}

(Received: April 14, 2017; Accepted: May 10, 2017)

\begin{abstract}
The article is devoted to the study of technological bases of processing of phosphate waste - cottrell dust and vermiculite as a stabilizing additive in a liquid complex fertilizer. Target of the research work were implemented as a result of engaging in technological conversion of solid industrial waste - cottrell dust. While cottrell dust was used as a phosphorus raw material, and vermiculite as the substrate, for mulching and aeration of the soil, nourishes the plants with minerals. Results of studies allowed to establish as a optimal regime parameters of the process of obtaining liquid complex fertilizers.
\end{abstract}

Keywords: chemical industry, cottrell dust, recycling, industrial waste, liquid complex fertilizer.

\section{INTRODUCTION}

Liquid fertilizers are water solutions or slurries of mineral and some organic nutrients. The most common mineral nitrogen - and phosphoruscontaining liquid complex fertilizers. This product group includes solutions of salts containing two or three major nutrients $(\mathrm{N}, \mathrm{P}, \mathrm{K})$ and macronutrients $(\mathrm{Ca}, \mathrm{Mg}, \mathrm{S})$ and micronutrients $(\mathrm{Fe}, \mathrm{Mn}, \mathrm{B}, \mathrm{Cu}$,
$\mathrm{Zn}$, Mo, Co). Nitrogen-phosphorus liquid complex fertilizer are solutions of phosphates of ammonium, obtained by high temperature treatment with ammonia, $\mathrm{H}_{3} \mathrm{PO}_{4}$ or polyphosphoric acids ${ }^{1}$.

\section{MATERIAL AND METHODS}

Unlike the traditional methods, for the production of housing services uses a mixture of 
cottrell dust, vermiculite and humic acid $a^{2}$ various ratios. Vermiculite of Kulantau field ${ }^{3}$ having the following composition: $\mathrm{SiO}_{2}-37,44, \mathrm{CaO}-2,10$, $\mathrm{MgO}-23,88, \mathrm{~K}_{2} \mathrm{O}+\mathrm{Na}_{2} \mathrm{O}-1,18, \mathrm{Fe}_{2} \mathrm{O}_{3}-6,01, \mathrm{Al}_{2} \mathrm{O}_{3}$ - 11,23, $\mathrm{H}_{2} \mathrm{O}-17,18$, used as stabilizing additive ${ }^{4}$. Pre-synthesized humic acid with $\mathrm{pH}=0,760$, as in previous works, is used as a substitute for sulphuric, nitric or phosphoric acids.

It was established that the composition cottrell dust ${ }^{5}$ meets the following content, \%: $\mathrm{P}_{2} \mathrm{O}_{5}$ total - 25, $\mathrm{K}_{2} \mathrm{O}-5, \mathrm{Na}_{2} \mathrm{O}-1, \mathrm{SiO}_{2}-25, \mathrm{CaO}-10$, $\mathrm{MgO}-1, \mathrm{Al}_{2} \mathrm{O}_{3}-3, \mathrm{Fe}_{2} \mathrm{O}_{3}-1, \mathrm{C}-24$.

A mixture of finely cottrell dust, activated water, vermiculite, of a dilution solution consisting of potassium sulphate and $30 \%$ ammonium sulphate is decomposed by humic acid at a temperature of $60^{\circ} \mathrm{C}$ and 90 minutes. The addition of solutions of potassium sulphate and ammonium sulphate increases ${ }^{6}$ potassium and nitrogen and consequently in the composition of the liquid complex fertilizer ${ }^{7}$.

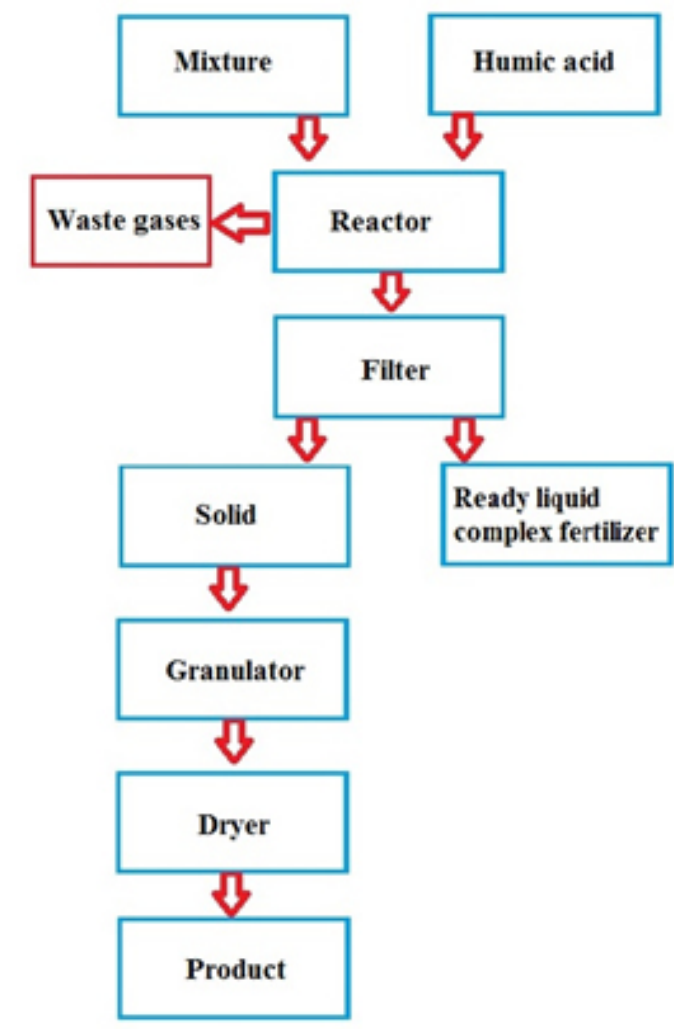

Fig. 1: Process flow diagram of receiving liquid complex fertilizer with a stabilizing additive
The process chemistry is possible will present as follows 8,9

$\mathrm{Ca}_{5}\left(\mathrm{PO}_{4}\right)_{3} \mathrm{~F}+6$ Humic Acid $+2\left(\mathrm{NH}_{4}\right)_{2} \mathrm{SO}_{4}$ $+\mathrm{K}_{2} \mathrm{SO}_{4}+\mathrm{H}_{2} \mathrm{O}=2 \mathrm{CaSO}_{4}+\mathrm{NH}_{4}(\mathrm{Hum})+\mathrm{H}_{3} \mathrm{PO}_{4}+$ $2 \mathrm{Ca}(\mathrm{Hum})_{2}+\mathrm{Ca}\left(\mathrm{H}_{2} \mathrm{PO}_{4}\right)_{2}+\mathrm{HF}+2 \mathrm{KHum}$

Process flow diagram for synthesizing the liquid complex fertilizer is shown in Fig. 1.

The mixture after decomposition is filtered. It is established that the obtained liquid phase has a density of 1.2 and $\mathrm{pH}=2,7$.

The resulting solution is analyzed for the content of assimilable and water-soluble $\mathrm{P}_{2} \mathrm{O}_{5}$, ammonia and nitrogen.

\section{RESULTS AND DISCUSSION}

Laboratory work has been tested in the laboratory of the Department Chemical technology of inorganic substances, M. Auezov SKSU, and physicochemical analyse ${ }^{10}$ were performed in the Regional Laboratory Test Engineering Profile (RLTEP) on the basis of the M. Auezov SKSU.

The resulting product has the following material composition:

Physicochemical features derived from cottrell dust liquid complex fertilizer. Using a scanning electron microscope is performed elementby-element and mineralogical analysis of its composition. The results of the microscopic studies allowed to image the surface of samples and the spectra of individual points, with the idea element by element, and percentage composition, as well as diffraction peaks of individual elements with high

Table 1. Physico chemical parameters obtained in the laboratory liquid complex fertilizer

\begin{tabular}{lll}
\hline $\mathbf{N}_{0}$ & Name of indicators & Indicators \\
\hline 1 & $\begin{array}{l}\text { Mass fraction of total } \\
\text { phosphates, \% }\end{array}$ & 11,3 \\
2 & $\begin{array}{l}\text { Mass fraction of assimilable } \\
\text { phosphates, \% }\end{array}$ & 11,0 \\
3 & $\begin{array}{l}\text { Mass fraction of total } \\
\text { nitrogen }(\mathrm{N}), \%\end{array}$ & 0,75 \\
\hline
\end{tabular}


Table 2: Element wise composition of liquid complex fertilizer, calcined at $500^{\circ} \mathrm{C}$

\begin{tabular}{lcc}
\hline Element & $\begin{array}{c}\text { Weight } \\
\text { composition, } \\
\%\end{array}$ & $\begin{array}{c}\text { Weight } \\
\text { composition, } \\
\text { in terms } \\
\text { of oxide, } \%\end{array}$ \\
\hline $\mathrm{O}$ & 54,07 & - \\
$\mathrm{Na}$ & 1,38 & 1,86 \\
$\mathrm{Mg}$ & 1,30 & 2,15 \\
$\mathrm{Al}$ & 0,31 & 0,58 \\
$\mathrm{P}$ & 27,52 & 63,04 \\
$\mathrm{~S}$ & 0,48 & 1,20 \\
$\mathrm{Cl}$ & 0,98 & - \\
$\mathrm{K}$ & 9,16 & 11,95 \\
$\mathrm{Ca}$ & 3,99 & 5,58 \\
$\mathrm{Mn}$ & 0,22 & 0,28 \\
$\mathrm{Zn}$ & 0,49 & 0,60 \\
$\mathrm{Fe}$ & 0,10 & 0,12 \\
\hline
\end{tabular}

Table 3: Element wise composition of solids

\begin{tabular}{llc}
\hline Element & $\begin{array}{l}\text { Weight } \\
\text { composition, } \\
\%\end{array}$ & $\begin{array}{c}\text { Weight } \\
\text { composition, } \\
\text { in terms } \\
\text { of oxide, \% }\end{array}$ \\
\hline $\mathrm{O}$ & 43,95 & - \\
$\mathrm{Na}$ & 1,48 & 1,99 \\
$\mathrm{Mg}$ & 1,98 & 3,28 \\
$\grave{A}^{2}$ & 2,77 & 5,23 \\
$\mathrm{Si}$ & 19,49 & 41,68 \\
$\mathrm{P}$ & 10,96 & 25,19 \\
$\mathrm{~S}$ & 2,28 & 5,70 \\
$\mathrm{Cl}$ & 0,52 & - \\
$\mathrm{K}$ & 4,85 & 6,32 \\
$\mathrm{Ca}$ & 9,11 & 12,74 \\
$\mathrm{Mn}$ & 0,24 & 0,30 \\
$\mathrm{Zn}$ & 0,86 & 1,06 \\
$\mathrm{Fe}$ & 0,53 & 0,67 \\
\hline
\end{tabular}
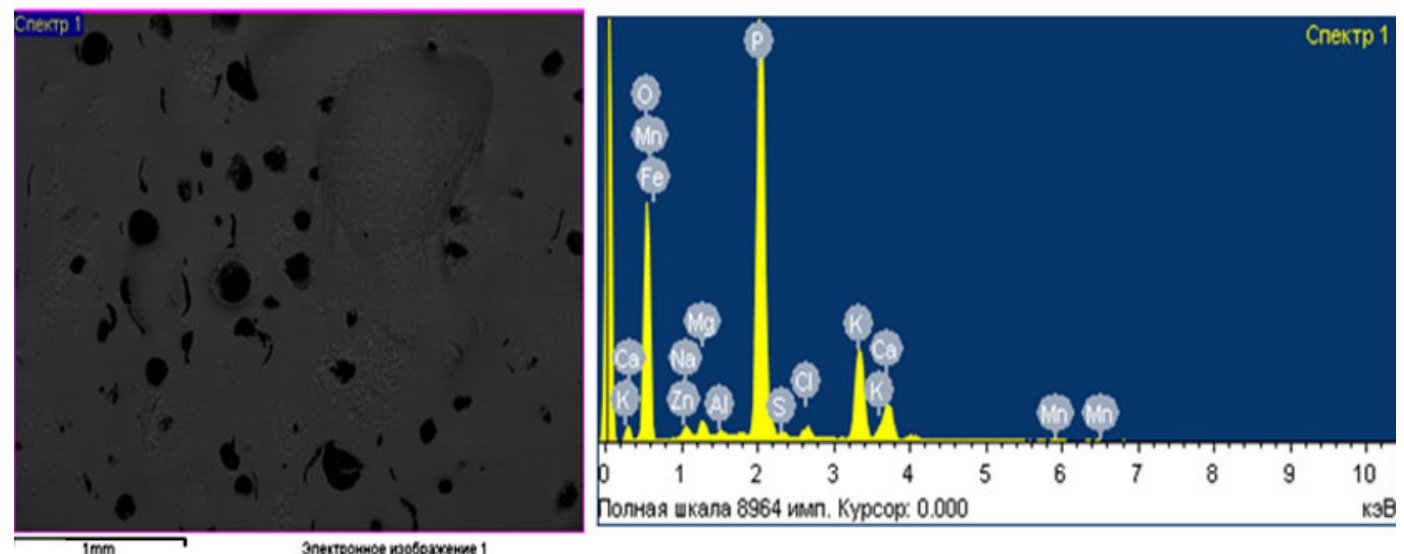

Fig. 2: Microscopic picture of liquid complex fertilizers
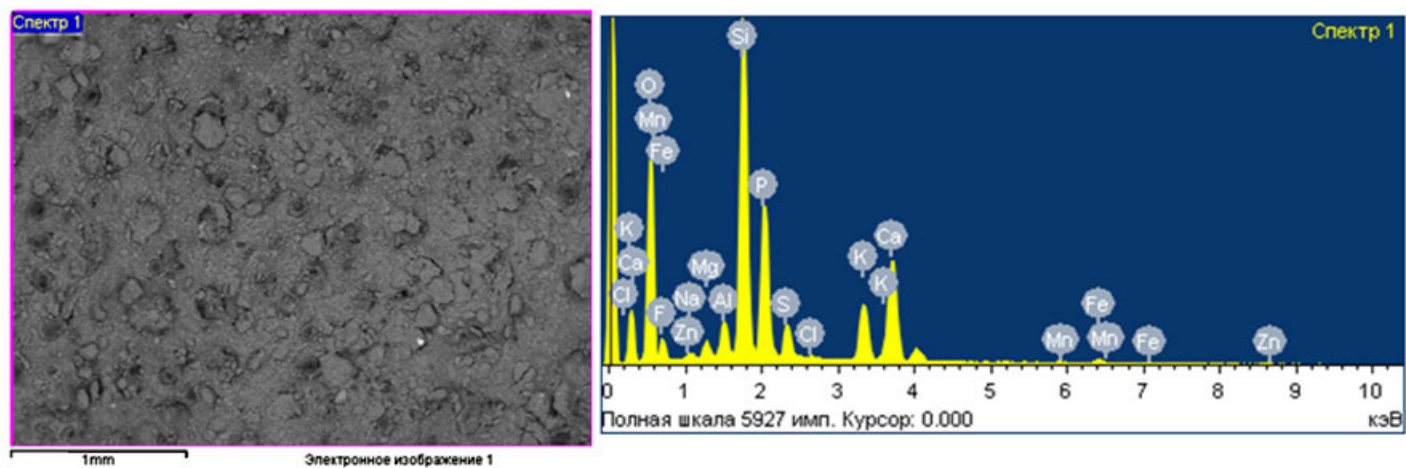

Fig. 3: Microscopic picture of solids after filtration 
spatial resolution and the desired depth of field of view.

Microscopic picture and the results of elemental analysis of the liquid complex fertilizer is presented in fig. 2 and table 2.

The dry residue remaining after filtration is also is a useful product which corresponds to a double super phosphate low grade (Fig.3, table 3). The residue is granulated and dried at a temperature of $100-110^{\circ} \mathrm{C}$ in $3-5$ hours. The obtained dry residue has the following physical characteristics, \%: $\mathrm{P}_{2} \mathrm{O}_{5}$ total - 20; $\mathrm{P}_{2} \mathrm{O}_{5}$ assimilable-15; $\mathrm{P}_{2} \mathrm{O}_{5}$ water-soluble8,75 .

IR spectral analysis of liquid complex fertilizers was conducted on the instrument IR spectrometer Shimadzu IR Prestige-21. In table 4 and fig. 4 shows the main peaks according to the results of IR spectral analysis of liquid complex fertilizers.

IR spectra of the studied ${ }^{10}$ samples of the liquid complex fertilizers are characterized by intense peaks of the broad bands of absorption with satellites

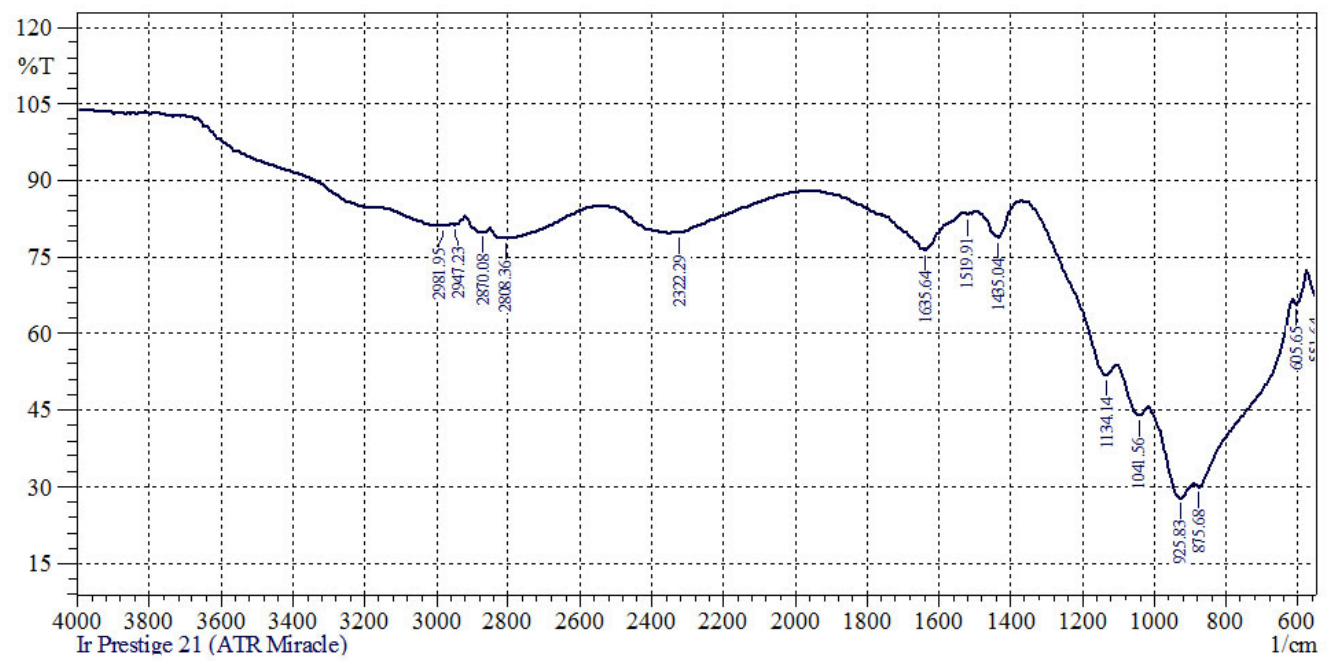

Fig. 4: IR spectral analysis of liquid complex fertilizers

Table 4: The peaks in the IR-spectral analysis of liquid complex fertilizers

\begin{tabular}{lccccccc}
\hline No. & Peak & Intensity & Corr.intensity & Base & Base & $\begin{array}{c}\text { Area } \\
\text { (H) }\end{array}$ & $\begin{array}{c}\text { Corr.area } \\
\text { (L) }\end{array}$ \\
\hline & & & & & & & \\
1 & 551,64 & 67,192 & 0,980 & 574,79 & 547,78 & 4,367 & 0,098 \\
2 & 605,65 & 65,697 & 2,139 & 613,36 & 578,64 & 5,902 & 0,385 \\
3 & 875,68 & 29,990 & 2,608 & 891,11 & 617,22 & 98,804 & 4,773 \\
4 & 925,83 & 27,691 & 6,704 & 1014,56 & 894,97 & 56,342 & 4,823 \\
5 & 1041,56 & 43,898 & 3,995 & 1103,28 & 1018,41 & 27,792 & 1,816 \\
6 & 1134,14 & 51,955 & 5,310 & 1365,60 & 1107,14 & 43,230 & 2,061 \\
7 & 1435,04 & 78,933 & 6,091 & 1496,76 & 1381,03 & 9,916 & 1,740 \\
8 & 1519,91 & 83,358 & 0,458 & 1557,62 & 1500,62 & 2,100 & 0,040 \\
9 & 1635,64 & 76,504 & 8,317 & 1932,67 & 1531,48 & 33,421 & 6,617 \\
10 & 2322,29 & 79,715 & 0,201 & 2330,01 & 1978,97 & 26,267 & 0,041 \\
11 & 2808,36 & 78,723 & 2,333 & 2846,93 & 2549,89 & 26,765 & 2,349 \\
12 & 2870,08 & 79,866 & 1,492 & 2916,37 & 2850,79 & 6,201 & 0,459 \\
13 & 2947,23 & 81,359 & 0,461 & 2954,95 & 2920,23 & 2,994 & 0,063 \\
14 & 2981,95 & 80,959 & 0,879 & 3151,69 & 2958,80 & 16,234 & 0,590 \\
\hline
\end{tabular}


Table 5. The peaks in the IR-spectral analysis of dry residue after filtration

\begin{tabular}{cccccccc}
\hline No. & Peak & Intensity & Corr.intensity & $\begin{array}{c}\text { Base } \\
\text { (H) }\end{array}$ & $\begin{array}{c}\text { Base } \\
\text { (L) }\end{array}$ & Area & Corr.area \\
\hline 1 & 563,21 & 69,162 & 3,293 & 578,64 & 547,78 & 4,671 & 0,336 \\
2 & 601,79 & 70,888 & 5,015 & 621,08 & 582,50 & 5,134 & 0,450 \\
3 & 655,80 & 77,998 & 0,153 & 659,66 & 640,37 & 2,057 & 0,013 \\
4 & 675,09 & 77,475 & 0,115 & 678,94 & 659,66 & 2,104 & 0,004 \\
5 & 802,39 & 68,978 & 4,538 & 840,96 & 686,66 & 20,773 & 1,387 \\
6 & 910,40 & 66,648 & 3,849 & 956,69 & 844,82 & 18,315 & 1,522 \\
7 & 1033,85 & 42,840 & 31,505 & 1330,88 & 960,55 & 59,024 & 25,826 \\
\hline
\end{tabular}

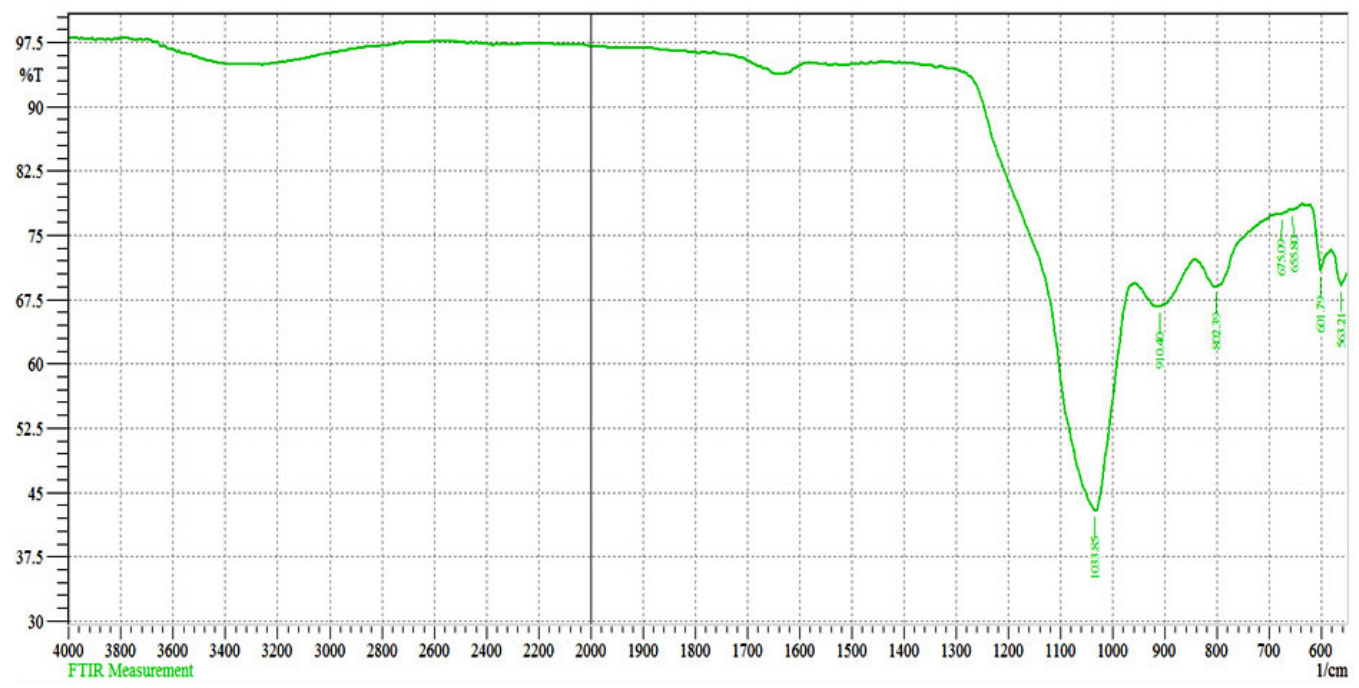

Fig. 5: IR spectral analysis of dry residue after filtration

in the areas of $500-900 \mathrm{~cm}^{-1}$ and $2600-3700 \mathrm{~cm}^{-1}$. It should be noted that the wavelengths in the absorption region of $550-700 \mathrm{~cm}^{-1}$ is characteristic for alkanes and alkene with communication $\mathrm{RC} \equiv \mathrm{CH}$, and $850-900 \mathrm{~cm}^{-1}$ for compounds alkane and alkene of a number of types of the $\mathrm{C}=\mathrm{C}=\mathrm{C}$. The peaks of intensive absorption in the region of $2600-3700 \mathrm{~cm}^{-1}$ characterizes carbonyl group aromatic a number of types $\mathrm{CH}_{2}-\mathrm{COOH}, \mathrm{C}=\mathrm{C}-\mathrm{COOH}$.

In table 5 and fig. 5 shows the main peaks according to the results of infrared spectral analysis of dry residue after filtration.

From fig. 5 and table 5 data follows

1049-1060 absorption spectra with wavelengths characteristic of phosphorus compounds, $\mathrm{P}=\mathrm{O}$ (with hydrogen bonds) 952-906 typical P-F and phosphates absorption spectra with wavelengths of 10201090 characterize the presence of cottrell dust in compounds of silicates with valence relations $\mathrm{Si}-\mathrm{O}-\mathrm{Si}$

absorption spectra in the region 800-802 characteristic of silicate compounds charge materials in the valence state of Si-O-Ca and Si-O-Al ${ }^{10}$

Studied optimal regime parameters to the production of liquid complex fertilizers. The results are shown in table 6 and fig. 6.

From table 3.2 it is seen that the optimal regime indicators developed technology for production of liquid complex fertilizers are 


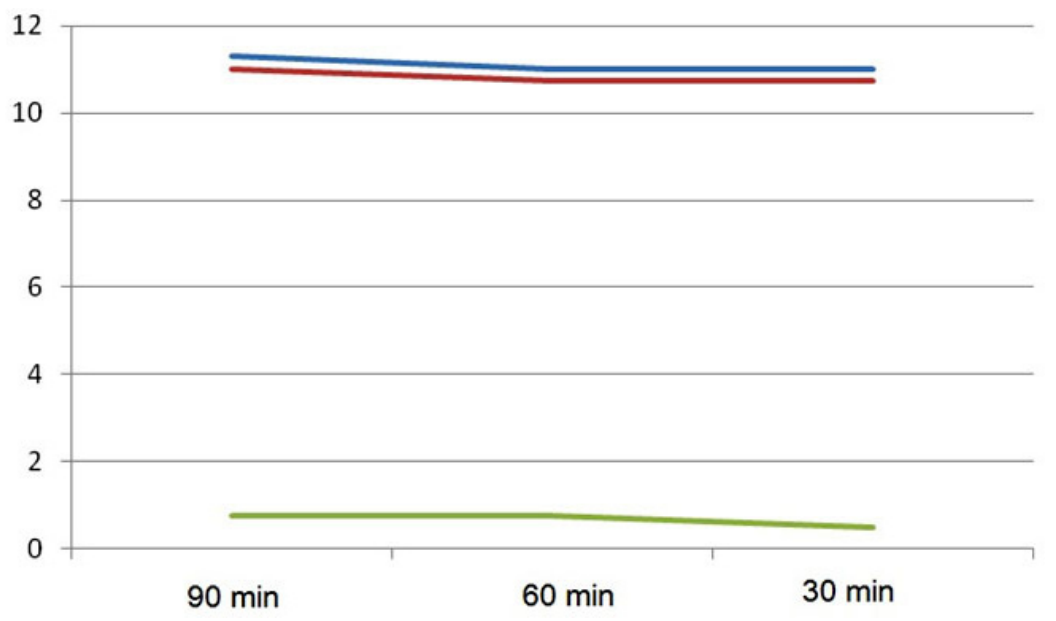

Fig. 6: The dependence of the process at $60^{\circ} \mathrm{C}$

Table 6: The results of the research of optimal regime parameters

\begin{tabular}{|c|c|c|c|}
\hline Time, min & $\mathrm{P}_{2} \mathrm{O}_{5 \text { total }}, \%$ & $\mathrm{P}_{2} \mathrm{O}_{5}$ assimilable, $\%$ & $\mathrm{~N}, \%$ \\
\hline 1 & 2 & 3 & 4 \\
\hline \multicolumn{4}{|c|}{$30^{\circ} \mathrm{C}$} \\
\hline 90 & 9,5 & 9,0 & 0,5 \\
\hline 60 & 9,4 & 8,36 & 0,5 \\
\hline 30 & 9,0 & 7,76 & 0,12 \\
\hline \multicolumn{4}{|c|}{$40^{\circ} \mathrm{C}$} \\
\hline 90 & 9,75 & 9,0 & 1,0 \\
\hline 60 & 9,6 & 8,75 & 0,75 \\
\hline 30 & 9,5 & 8,5 & 0,75 \\
\hline \multicolumn{4}{|c|}{$60^{\circ} \mathrm{C}$} \\
\hline 90 & 11,3 & 11,0 & 0,75 \\
\hline 60 & 11,0 & 10,75 & 0,75 \\
\hline 30 & 11,0 & 10,75 & 0,5 \\
\hline \multicolumn{4}{|c|}{$75^{\circ} \mathrm{C}$} \\
\hline 90 & 10,3 & 10,0 & 0,5 \\
\hline 60 & 10,3 & 9,8 & 0,5 \\
\hline 30 & 10,0 & 9,75 & 0,3 \\
\hline
\end{tabular}

temperature $-60^{\circ} \mathrm{C}$

- $\quad$ for the duration of the process $-90 \mathrm{~min}$.

\section{CONCLUSION}

Thus, on the basis of a mixture of phosphorus sludge and vermiculite in conditions of temperature 60 degrees and at optimum process duration of 90 minutes it is possible to obtain liquid complex fertilizer with the content of assimilable phosphoric anhydride $-11 \%$, nitrogen is $0.75 \%$, zinc is $0.60 \%$; the dry residue obtained after the stage filtration, is composed of : phosphor - of $10.96 \%$ (calculated as $\mathrm{P}_{2} \mathrm{O}_{5}-25 \%$, including $\mathrm{P}_{2} \mathrm{O}_{5}$ assimilable $-15 \%$, $\mathrm{P}_{2} \mathrm{O}_{5}$ water-soluble $-8,75 \%$ ), in line with double superphosphate; the source of the vermiculite used in the process of decomposition of the phosphate of secondary raw materials, is a highly effective stabilizing additive, which are used to improve soil structure, referred to as the "agronomic" rock. The residual part of the utility and double superphosphate humic acid will fulfill the role of organic-mineral additives, which improve the soil structure, and show the quality of the protective compositions of plants from pests and diseases. 


\section{REFERENCES}

1. Kapranov, V.N., The use of natural fertilizers and mineral nutrition of field crops. Author's abstract of Doctoral thesis. Moscow, 2009.

2. Nazarbek, U.B.; Besterekov, U; Petropavlovsky, I.A.; Nazarbekova, S.P.; Beisenbayev, O.K., Orien. J. Chem., 2015, 31(3), 1409-1416.

3. The field of mining raw materials of Kazakhstan: guide. Almaty, 2000.

4. Ivanova, L.A.; Kotelnikov, V.V.; Bykova, A.E., Physico-chemical transformation of the mineral vermiculite into the substrate for growing plants. Bulletin of MSTU, 2006, 9 , 885-891.

5. Nazarbek, U.B.; Besterekov, U; Nazarbekova, S.P.; Bolysbek A.A., Orien. J. Chem., 2015, 31(1), 215-221.

6. Ulianova, O.A., Ecological and agrochemical assessment of fertilizer compositions to increase the productivity of the system soilplant. Author's abstract of Doctoral thesis. Ulan-Ude, 2011.

7. Bolatbekuly, O.; Aitureyev, M.; Nazarbek, U.B., Bulletin of KazNRTU, 2016, 6(118), 541-545.

8. Nazarbek, U.B.; Besterekov, U; Nazarbekova, S.P.; Beisenbayev, O.K.; Bolysbek A.A., Orien. J. Chem., 2016, 32(4), 2027-2033.

9. Besterekov, U; Nurasheva, K.K.; Nazarbek, U.B.; Nazarbekova, S.P.; Bolysbek A.A., Orien. J. Chem., 2017, 33(1), 92-103.

10. Nakhmanson, M.S.; Feklichova, V.G., Diagnosis of the composition of materials $\mathrm{x}$-ray diffraction and spectral methods. Leningrad, 1990. 